NBER WORKING PAPER SERIES

\title{
SOVEREIGN DEBT: IS TO FORGIVE \\ TO FORGET?
}

Jeremy Bulow

Kenneth Rogoff

Working Paper No. 2623

NATIONAL BUREAU OF ECONOMIC RESEARCH

1050 Massachusetts Avenue

Cambridge, MA 02138

June 1988

This research has been supported by grants from the National Science Foundation and the Alfred P. Sloan Foundation. The authors are grateful to Faruk Gul for helpful discussions on an earlier draft. The research supported here is part of the NBER's research program in International Studies. Any opinions expressed are those of the authors and not those of the National Bureat of Economic Research. 
NBER Working Paper \#2623

June 1988

Sovereign Debt: Is to Forgive to Forget?

\begin{abstract}
International lending to a less-developed country cannot be based on the debtor's reputation for making repayments. That is, loans to LDCs will not be made or repaid unless foreign creditors have legal or other direct sanctiors they can exercise against a sovereign debtor who defaults. Even if some lending is feasible because of direct sanctions, having a reputation for repayment in no way enhances a small LDC's ability to borrow.
\end{abstract}

Jeremy Bulow

Graduate School of Business

Stanford University

Stanford, CA 94305

(415) $723-2160$
Kenneth Rogoff

Economics Department

University of Wisconsin

Madison, WI 53706-1393

(608) 263-3876 


\section{INTRODUCTION}

The period from 1973 to 1982 saw a starting increase in the volume of international loans to less-developed countries. A central issue in analyzing LDC loan contracts is whether, and by what mechanism, these contracts can be enforced. ${ }^{1}$ Whereas domestic loans are generally supported by substantial collateral, the assets that can be appropriated in the event of a foreign sovereign's defaule are generally negligible. ${ }^{2}$ For this reason one must look beyond collateral to find incentives for repayment.

One approach, first explored by Eaton and Gersovitz (1981). and adopted by many others since ${ }^{3}$, assumes that creditors have no legal rights whatsoever (including even the right to seize the county's assets abroad). This line of research holds that a small LDC is able to borrow abroad only if it can maintain a reputation for repaying its loans. Lenders are willing to rely on a country's "reputation for repayment (so the argument goes) because they believe that if a country ever fails to honor its implicit debt contract, it will tarnish its reputation and risk being cut off from international capital markets in the future.

1 Theories that ignore contract enforcement problems suggest that there should be far greater integration of world capital markets than currently occurs. For a survey of the empirical evidence on international capital mobility, see obstfeld (1986).

2. Though Iran in 1979 was an exception.

3 other examples include Manuelli (1986), Eaton, Gersovitz and Stiglitz (1986). Grossman and Van Huyck (1987), and Cole and English (1987). Eaton and Gersovitz also considered direct punishments. 
The obvious appeal of pure reputation theories is that they seem robust to fnstitutional detail. One does not have to speculate on the legal rights of creditors within their own countries' courts, or on the ability of creditors to induce their governments to take retaliatory actions.

But we have come to query reputaton-for-repaymert theories, not to praise them. We prove, under rather general conditions, that reputation-for-repayment models cannot work. Loans to LDCs are possible only if creditors have legal rights such as the ability to impede a county's trade, or to seize its financial assets abroad (which is the real reason why a defaulter suffers reduced access to capital markets). 4 otherwise, creditors must be able to threaten the debtor's interests outside its borrowing relationships. (E.g., creditors may be able to persuade their governments to intervene militarily.) Having a good reputation for repaying foreign loans does not in any way enhance the ability of a small LDC to borrow abroad.

4 For a discussion of the legal evidence on this point, and an assessment of its probable empirical significance, see Bulow and Rogoff (1987), or Alexander (1987). 


\section{THE MODEL}

Our paradigm is of a small country that faces competitive, risk-neutral foreign investors. 5 The country is small in the sense that it cannot affect the world interest rate r.

The country is inhabited by a single, infinitely-lived representative agent. Since the proof of our theorem is based on an arbitrage argument, it is not necessary to place any restrictions on the agent's utility function other than that she prefers having more to having less.

There is one good, which the country both produces and consumes. The country's production function is given by

$$
y_{t}=E\left(\vec{\theta}_{t}, \vec{I}_{t-1}\right)
$$

where $y$ denotes output, and $t$ subscripts denote time. $\vec{\theta}_{t}=\left(\theta_{t}, \theta_{t-1}, \theta_{t-2}, \cdots\right) ;$ the $\theta_{i}$ 's are exogenous, seriallyindependent disturbance terms $\ldots \vec{I}_{t-1} \neq\left(I_{t-1}, I_{t-2}, I_{t-3}, \ldots\right)$, where $I_{t}$ is investment in period $t$. Net exports in period $t x_{t}$ are given by

$$
X_{t}=y_{t}-I_{t}-c_{t}
$$

$c, I \geq 0 ; y>0 ; x_{t} \geq-Y_{t}$, where c is the country's consumption and $Y$ is the output of the rest of the world.

The sequence of events within any given period $t$ is as follows: First, a shock $\theta_{t}$ occurs which affects output in the

5 It is straightforward to extend our analysis to the case of risk-averse foreign lenders. 
4

current period and possibly in future periods. After observing the shock, the country decides how to divide $y_{t}$ between It, ct. and $X_{t}$. Net exports can be used either to make payments on yarious loans, or to increase asset holdings abroad. ${ }_{t}$ and It can be observed by everyone; there is no private information about aggregate variables, 6

It is not necessary here to formally characterize the benefits a sma11 courtry might get from having access to world capital markets. Fundantally, however, the main benefits all have to do with consumption smoothing. ${ }^{7}$ Through short-term borrowing and lending, a country can avoid having to match the exact timing of import expenditures and export receipts. Having access to long-term loans allows a country to maintain consumption levels in the short-term while taking advantage of high-yielding domestic investment opportunities. Finally, by taking advantage of world capital markets, a country can better insure itself against many types of risk (such as uncertainty over its terms of trade).

The world market value of a daim to the country's entire future gross income is given by

$$
W_{t}\left(\vec{\theta}_{t}, \vec{I}_{t-1}\right)=E_{t} \sum_{s=t}^{\infty} y_{s} /(1+r)^{s-t} \text {. }
$$

We assume that $W_{0}<\infty$, which implies that for any finite $t$,

6 We will discuss the case of private information later on. 7 See Eaton and Gersovitz (1981), and Eaton, Gersovitz and Stiglitz (1986). 
$W_{t}<\infty$ with probability one. ${ }^{8}$ The force of this assumption is to

rule out any "Ponzi"-type reputational contracts, under which a borrower can always expect, in present value terms, to be a net importer of capital over some finite horizon.

8

The assumption that $W$ is finite is slightly stronger thar the assumption that the market value of the country's net income (net of investment) is finite. However, the assumption that $W_{0}$ is finite can easily be replaced by the assumption that the market value of the world's net income is finite. All our. results go through under this alternative assumption, with only very minor changes in the proofs. 
III. TYPES OF LENDING CONTRACTS

In a pure reputation-for-repayment ("reputation") contract, a country's foreign creditors have no effective legal recourse in the event of default. They cannot interfere with the country"s trade; they canot even seize any financial assets it may hold abroad. The worst fate that can befali a country wich defauts on a reputation contract is that it will never again be allowed to write reputation contracts. However, the defaulting country cannot be cut off from international capital markets entirely Though it may no longer be able to borrow for domestic investment, it can still buy consumption-insurance contracts by paying cash in advance. A "cash-in-advance" contract is just a conventional insurance contract under which a country makes a payment up front in return for a state-contingent, non-negative future payment. Implicitly, we are assuming that there are foreign investors who can make commitments. These commitments are enforced by the legal system in investors countries. Thus a small country can hold foreign assets such as bank accounts. treasury bills, stocks and other state-contingent assets. 9 of course, it can also stockpile reserves of precious metals and foreign currency.

\section{A. Reputation Contracts}

Suppose the country were allowed to have a reputation

9 Notable efforts to study international lending in a general equilibrium framework include Manuelii (1986) and Cole and English (1987). 
contract which, in essence, is an implicit contract. For our purposes, it is not necessary to ask what set of off-theequilibrium-path beliefs might support the contract, nor is it important to ask whether the contract is optimal in any sense. 10 Al1 one needs to know is that any. reputation contract must implicitly specify a state-contingent payment $P_{t}\left(\vec{\theta}_{t}, \vec{I}_{t-1}\right)$ for al1 possible realizations of $\vec{\theta}_{t}$ and $\vec{I}_{t-1}$, and for all $t$, where $y_{t} \geq P_{t} \geq-Y_{t} \cdot 11$

Note that for an implicit contract to be equilibrium, it must be in the country's interest to honor the contract in every possible state of nature. In particular, the country must never have an incentive to defaul on its reputation contract and switch completely over to cash-in-advance contracts: Cotherwise; the contract is not the true implicit contract.)

Given the implicit contract, one can write the world market value of the country's reputation debt at time $t, D_{t}$, as the expected present-discounted value of its future repayments:

10

For example, the candidate equilibrium can involve trigger-strategies as in Eaton and Gersovitz (1981), Eaton, Gersovitz and Stiglitz (1986), and Grossman and Van Huyck (1987). Alternatively, the equilibrium can involve lenders having imperfect information about the country's utility function (provided they know that it has a positive marginal utility of consumption).

11 This specification does not preclude randomized strategies. One can view $\theta$ as a vector, one of whose elements has no effect on fundamentals such as output. If the foreign. investor can make legal comitments, then the implicit contract and the explicit legal contract will coincide whenever $P \leq 0$. In states of nature where $P \geq 0$, any explicit legal contract is meaningless, by assumption. 


$$
D_{t}\left(\vec{\theta}_{t}, \vec{I}_{t-1}\right) \equiv E_{t}\left\{\sum_{s=t}^{\infty} F_{s} /(1+r)^{s-t}\right\} .
$$

Clearly, $D_{t}$ can never exceed $W_{t}$, the world market value of a claim to the country's entire future output stream. Thus within any reputational equilibrium there must exist some $k^{\prime}$,

$0 \leq k^{\prime} \leq 1$, such that with probability one $\forall t$,

$$
D_{t}\left(\vec{\theta}_{t}, \vec{I}_{t-1}\right) \leq k^{\prime} W_{t}\left(\vec{\theta}_{t}, \vec{I}_{t-1}\right), \forall \vec{\theta}_{t}, \vec{I}_{t-1} \text {. }
$$

Let $k$ be the smallest $k^{\prime}$ such that condition (5) holds.

\section{B. Cash-in Advance Contracts}

In a cash-in-advance contract, the country pays the amount $A_{t}$ at the end of period $t$ in exchange for a contract which pays $G_{t+1}\left(\vec{\theta}_{t+1}, \vec{I}_{t}\right)$ in period $t+1$. (A cash-in-advance contract can always be indexed to all the same variables as the implicit reputation contract. ${ }^{12}$ ) Even if the country has forfeited its reputation for honoring contracts, a foreign investor should always be willing to accept a cash-in-advance contract as long as it satisfies two requirements ${ }^{13}$ :

$$
E_{t}\left(G_{t+1}\left(\vec{\theta}_{t+1}, \vec{I}_{t}\right)\right\}=(1+r) A_{t},
$$

12 We shall discuss the issue of indexation in more detail later in section $V$.

13 Here we are only defining one-period cash-in-advance contracts. In principle, the country could make a payment in -1 in exchange for (strictly positive) state-contingent payments in $t, t+1, t+2, \epsilon t c$. It can be shown, however, that multi-period cash-in-advance contracts are superfluous. 


$$
G_{t+1}\left(\vec{\theta}_{t+1}, \vec{I}_{t}\right) \geq 0
$$

Condition (6) states that the contract must offer the riskneutral foreign investor the market rate of return. Condition (7) says that there can be no state of nature in which the country is called upon to make positive payments in period $t+1$. obviously, one must also have $A_{t} \geq 0$, but this condition holds whenever (6) and (7) hold. If one thinks of the inftial payment $A_{t}$ as being collateral, then condition (7) can be interpreted as saying that the country's collateral must be sufficient to cover its losses on the contract even in the worst possible state of nature. 
IV. NON-EXISTENCE OF SUPPORTABLE REFUTATION CONTRACTS.

\section{A. Reputation contracts in the absence of direct punishments}

We are now ready to state the central theorem of this paper:

Theorem 1: In any sequential equilibrium, $D_{t} \leq 0 \forall t$.

Rroof: Suppose $D_{s} \geq k\left(w_{s}-y_{s}\right)$. Then the country can cease payment on its reputation contract and initiate the following sequence of cash-in-advance contracts:

For ali $t \geq s$, invest $A_{t}$ in return for a payment of $G_{t+1}$ in the ensuing period where:

$$
\begin{aligned}
& \left.A_{s}\left(\vec{\theta}_{s}, \vec{I}_{s-1}\right)=\vec{P}_{s}\left(\vec{\theta}_{s}, \vec{I}_{s-1}\right)+k_{(W}-y_{s}\right)-D_{s}, \\
& A_{t}\left(\vec{\theta}_{t}, \vec{I}_{t-1}\right)=G_{t}\left(\vec{\theta}_{t}, \vec{I}_{t-1}\right)+P_{t}\left(\vec{\theta}_{t}, \vec{I}_{t-1}\right)-k_{t}, \forall t>s, \\
& G_{t}\left(\vec{\theta}_{t}, \vec{I}_{t-I}\right)=k_{t}\left(\vec{\theta}_{t}, \vec{I}_{t-1}\right)-D_{t}\left(\vec{\theta}_{t}, \vec{I}_{t-1}\right), \forall t>s .
\end{aligned}
$$

Since $D_{t} \leq \mathrm{kW}_{t}$, inspection of (10) indicates that condition (7) is satisfied. We note from (3) that

$$
E_{t}\left(W_{t+1}\right)=(1+r)\left(W_{t}-y_{t}\right)
$$

and Erom (4) that

$$
E_{t}\left(D_{t+1}\right)=(i+r)\left(D_{t}-P_{t}\right)
$$

Straightforward substitution of (11) and (12) into (8), (9) and (10) yields immediate confirmation of (6). Thus, the sequence of cash-in-advance contracts is feasible. Furthermore, note that instead of paying $P_{t}$ each period, the country must contribute 
only $A_{s} \leq P_{S}$ in period $s$ and $P_{t}-k y_{t} \leq P_{t}$ for $t>s$, with equality holding only when $k-0$. Thus $k$ must equal zero and by (5), $D_{C} \leq 0 \forall t$

Q.E.D.

Thus if one traces out the game tree governed by any reputation contract, there mst exist some node at which the country can switch to a sequence of cash-in-advance contracts which dominates the reputation contract. The collateral for the cash-in-advance contracts is drawn from funds the country would otherwise have used to pay back its reputation contract... Despite the fact that the collateral may at first be quite small, it is still sufficient to provide at least as much insurance as the country could have obtained under the reputation contract. A reputation contract can only be equilibrium under the unrealistic assumption that the country is not allowed to hold assets abroad.

\section{B. Reputation contracts when lenders have direct means for}

\section{punishing default}

In the preceding analysis, we assumed that holders of reputation contracts have no way to directly punish the country if it repudiaces. Here we show that if there are some direct costs which lenders can impose on a country in the event of default, then loans can sustained, but only on the basis of these costs. A good reputation for repaying loans will not in any way enhance a country's ability to borrow.

Suppose that lenders have the ability to impose a random penalty of $\pi_{t}\left(\vec{\theta}_{t}, \vec{I}_{t-1}, \eta_{t}\right)$ if a borrower stands in default in 
period $t$, where $\eta$ is independent of $\theta$ and $y_{t}>\pi_{t} \geq 0$. The penalty causes the country's period-t output to be reduced by $\pi_{t}$. Then we can generalize Theorem 1 as follows:

Theorem 2: In any sequential equilibrium,

$$
D_{t} \leq \Sigma_{t} \sum_{k=t}^{\infty} \pi_{k} /(1+r)^{k-t}, \quad \forall t .
$$

Eroof Ses Appendix.

Actually, the bound given by Theorem 2 may be too high, since countries can typically bargain with theit creditors. ${ }^{14}$ 


\section{v. LIMITATIONS AND EXTENSIONS}

Here we emphasize some limitations on the scope of our result.

\section{A. Reputation Outside the scope of the Lending Relationship}

What if repudiation damages a country's general image beyond just its reputation for repaying its loans? One might, for example, envision some countries as playing a tariff supergame, in which either raising tariffs or defaulting on foreign debt triggers a costly trade war such a mechanism could conceivably support a positive level of lending. 15 However. Thearent 2 directly applies to this case. The maximum amount the country is allowed to borrow must be governed strlctiy by the casts of a trade war. If the costs of a trade war are very small, then the amount the country can borrow is very small. We do not claim that reputation plays no role in international relations, only that a good reputation for repaying foreign loans does not enhance a small country's ability to borrow abroad.

\section{B. Non-Competitive Lenders}

Theorems 1 and 2 are based on the standard assumption that the country faces competitive forelgr investors. In some sense the essence of our result is that if there are no gains for the country in dealing with any specific lender, then reputation contracts are imposible. As long as the country faces

\section{Some of the broader incentives for repayment are} discussed by Feldstein, Decarmay. Narusawa and Krugman (1987, p. 41). 
competitive foreign investors, then any service provided by the current lender (e.g., insurance) can equally well be provided by a rew investor. It is possible, of course, that in practice there may be some efficiency gain in having the country continue to deal with its current lenders. However, the upper bound on any "zeputation" debt is stili only the real cost to the country of switching its business to a new set of financial institutions. It seems that this cost cannot be very large relative to the size of most LDC's foreign debts.

\section{c. Verifiability Problems in Contracting}

We have assumed that the country can hold assets abroad which are indexed to the same observable exogenous shocks, $\theta$, as in a reputation contract. An alternative assumption is that $\theta$ is "observable but not verifiable." 16 That is, the borrower, the lender, and all potential lenders observe $\theta$. However, either because it is cosely to verify $\theta$ in court, or due to costs of contracting, the country is precluded from ever holding foreign assets which are indexed to the shock. It is doubtful that this story can be used to explain reputation contracts of any significant size.

First, it is hard to see what kind of shock would be observable to a huge pool of potential (competitive) lenders, but yet cannot be put into contracts. (The concept of observable but not verifiable shocks works better in the context of a bilateral

16 Grossman and Van Huyck (1987) take this tack. 
monopoly relationship.) Second, wuch of the uncertainty that a small country faces is likely to be highly correlated with events elsewhere in the world. Commodity price uncertainty, for example, can clearly be hedged ir world asset markets. So, too, can shocks to world demand for the country's ather goods: certainly technology shocks are highly correlated with events elsewhere in the world. Even weather conditions can be highly correlated across countries. As long as the country is able to lend in world capital markets after a default. it ought to be able to construct a portfolio which is highly correlated with $\theta$. Finaliy, to the extent that foreign loans are used simply to smooth predictable seasonal fluctuations in income, verification is not an issue. (our theorem encompases this case.)

\section{Difficulties in observing the Country's Actions}

Theore 1 does not apply directly to the case where the country has private information, though an extension might be possible. 17 Suppose, for example, that investors observe output, $y(\theta, I)$, but they do not directly observe investment, I, or the shock, $\theta$. In this case, it is still possible to characterize any reputational equilibrium as an implicit contract, except that the country's payments, $P_{t}$ will only be a function of $\vec{y}_{t}=$ $\left(y_{t}, y_{t-1}, y_{t-2}, \ldots\right)$. As before, the country always has the option of switching over to cash-in-advance contracts, which can

17 Kletzer (1984) considers some implications of private information for LDC loan contracis. For a more recent example, see Atkeson (1987). 
also be indexed to $\vec{y}_{t}$. However, the terms of the postrepudiation cash-in-advance contracts will depend on investors' beliefs about $I_{s}$. Is-1, etc. If a default at time s adversely affects investors' beliefs about the country's capital stock, this will hurt its ability to get good terms on lts cash-inadvance contracts (since investors will attach a higher probability to low realizations of $y$ ). Of course, the country may still be better off than under the reputation contract, especially when $D_{t}=\mathrm{kW}_{t}$.

The difficulty here is that sequential equilibrium places no restrictions on investors' off-the-equilibrium path beliefs. ${ }^{18}$ The resulting multiplicity of sequential equilibria is endemic in models with private information. It seems unlikely that one can obtain a definite result in the present context without applying a refinement of sequential equilibrium, and without fully specifying the country's utility function and production function. We conjecture that the intuition underlying the present analysis should carry over to private information case, but the question can only be resolved after further research. one should be cautious about attaching too much weight to the importance of private information in the context of LDC loan contracts. For one thing, $\theta$ is an aggregate shock, and it is hard to argue that aggregate information can be private. We suspect that in the typical LDC, the country's leaders do not know any more about $\theta$ than do the country's major lenders. Also, 
as we have argued above in section $V, C$; $\theta$ is probably highly correlated with external variables, and therefore the component which can potentially be private information is minor.

\section{E. The Country's Preferences are Unobservable}

As long as the country's actions are observable, and as long as investors believe that the country prefers having more to having less, then it does not matter whether investors know the country's preferences exactly. Theorem l would stili apply:

F. Restrictions on the Use of Foreign-Currency Reserves

Some athors have tried to provide a role for reputation by assuming that a country cannot use its foreign-currency reserves to buy imports needed for investment. They assume that foreign investment goods can only b purchased with new loans 19 Thus a country can gain by repaying a lender p dollars from its foreign currency reserves in exchange for $P-$ c dollars worth of new loans.

We do not think such loans should be classified as "reputational", since the lender is assumed able to directly interfere with the country's trade. In any event, it is hard to justify the assumption that a country cannot buy the same goods with its own foreign-currency earnings that it can buy with lenders' foreign currency. We believe that the conventional assumption, that what a country can buy depends only on how much money it has available to spend, is the correct one.

19 See, for example. Eaton and Gersovitz (1983), Cole and English (1987), or Grossman and Van Huyck (1987). 
VI. OTHER DEFICIENCIES IN REPUTATION-FOR-REPAYMENT MODELS

There are a number of empirical and theoretical problems with reputation-for-repayment models beyond those problems raised thus far. We have not even mentioned the coordination problem inherent in a reputation model with a huge number of potential lenders. How long will a country which defaults be shut out of credit markets? The greater the length of the "punishment period", the more a country can be lent. But each creditor must know how long other creditors will wait before resuming lending. of course, the coordination problem is mitigated if the legal system gives existing creditors equal seniority with any new lenders, as in real-world debt contracts. But then LDC debt contracts should be analyzed as a bargaining problem, not as a reputation-for-repayment problem.

Eichengreen (1987), and Lindert and Morton (1987) have shown that, historically, the ability of LDC's to participate in credit markets does not seem to depend on their past repayment records. It does depend on their volume of trade and their GNP.

Furthermore, as Wynne (1951) and Winkler (1933) document, it is typically necessary for a country to settje (reschedule) its past defauls before it is allowed access to new loans.

Finally, a legal/bargaining approach predicts that the countries of jurisdiction for international loans will be major creditor countries. Reputatior-for-repayment models make the falsifiable prediction that lerders should be equally willing to have contracts adjudicated in debtor-country courts. 


\section{CONCLUSIONS}

In reputational models of LDC borrowing, a country is willing to make transfers to foreign lenders in order to preserve its reputation for repaying debts. We have shown; under rather general conditions, that "reputation" (for repayment) contracts cannot be equilibrium unless the country is prohibited from holding assets abroad. But this prohibition seems to contradict the central premise of reputation-Eor-Iepayment models $\cdots$ that the only sanction creditors can impose in the event of a defaul is a refusa 1 to extend new loans. True, the set of assets available to the country in the world's vast and varied capital markets may not quite span. the set of shocks to which an implicit reputation contract can be indexed, But as long as it comes close, the maximum size of reputation contracts is quite linited. We believe that Western loans to small developing counties in Eact depend on the legal and political rights of lenders within their own countries 20 The reason that an LDc cannot simply default on its loans and switch to cash-in-advance capital market transactions is that existing creditors can seize its assets abroad. 21 Adnittedly, there are many uncertainties

20 For a detailed discussion, see Bulow and Rogoff (1987), or Alexander (1987). Lenders are able to hinder a defaulter's goods market transactions as well as its capital market transactions. As we argue in our earlier paper, the main cost of repudiation may well be in lost gains from trade.

21 Eaton, Gersovitz and Stiglitz (1986) argue that insurance and consumption smoothing can only provide a motive for debt repayments in an infinite-horizon context. Their discussion is based on a reputational contract. In a contract backed up by legal rights, there is no need for the country's (leader's) 
surrounding the actual damage which a lender can inflict on an LDC; it is a gray area of Western $1 a w$. But if one wants to understand LDC loan contracts, then these costs must be studied further. Reputation for repayment considerations are at most a secondary factor.

If countries who default suffer rediced access to world capital markets, does it really matter whether reputational or legal sanctions are the cause? Yes. It certainly matters from an empirical perspective. If the cutoff is based on lenders' legal rights, then LDCs can bargain with their lenders, as in Bulow and Rogoff (1987). A borrower cannot bargain over trigger strategy beliefs. Because reputation-for-repayment models neglect a county's ability to bargain, they greatly overstate the ability of lenders to threaten to cut off an LDC from world capital markets. Thus they tend to overstate the empirical importance of capital market cutoffs relative to say, interference with the country's current account transactions.

The distinction between bargaining models and reputation models is also important for policy. A Western government poicy to force LDC loans through equity markets may be insensitive to the legal reasons why LDC loans have historicaliy been channelled through bank markets and bond markets. 22 Also, some have argued that debt forgiveness schemes may actually harm LDCs by causing

horizon to be infinite.

22 For a discussion of "debt-equity" swaps, see Helpman (1987). 
them to forfeit their reputation for repayment. We would argue that if, through bargaining, an LDC can induce its lenders to forgive a portion of its debts, it will gain. Debts which are forgiven will be forgotten. 
APPENDIX: FROOF OF THEOREY 2

Define

$$
I_{t} \equiv E_{t} \sum_{k=t}^{\infty} \pi_{k} /(I+r)^{k-t}
$$

Since $D_{t}$ can never exceed $W_{t}$, then there must exist some $q^{\prime}$. $0 \leq q^{\prime} \leq 1$, such that with probability one,

$$
D_{t}-\Pi_{t} \leq q^{\prime}\left(\theta_{t}-\Pi_{t}\right), \quad \forall \vec{\theta}_{t}, \vec{I}_{\tau-I}, \forall t .
$$

Let $q$ be the minimum $q^{\prime}$ such that condition (A.2) holds.

$D_{t}-\pi_{t}$ can be thought of as the amount of debt not supportable by direct sanctions, i.e., reputation debt.

Eroof of Theorem 2: Suppose $D_{s}-\pi_{s} \geq q\left[w_{s}-\Pi_{s}-\left(y_{s}-\pi_{s}\right)\right]$. Then the country can cease payment on its reputation contract and initiate the following sequence of cash-in-advance contracts:

For all $t \geq s$, invest $A_{t}$ in return for a payment of $G_{t+1}$ there:

$$
\begin{aligned}
& A_{s}=P_{s}-\pi_{s}+q\left[H_{s}-\pi_{s}-\left(y_{s}-\pi_{s}\right)\right]-\left(D-D_{s}\right), \\
& A_{t}=G_{t}+P_{t}-\pi_{t}-q\left(y_{t}-\pi_{t}\right), \quad \forall t>s, \\
& G_{t}=q\left(W_{t}-\Pi_{t}\right)-\left(D_{t}-\pi_{t}\right): \forall t>s . \\
& \text { Since } D_{t}-\Pi_{t} \leq q\left(W_{t}-\Pi_{t}\right) \text {, inspection of (A.5) indicates } \\
& \text { that condition (7) fis satisfied. } \\
& \text { We note that } \\
& E_{t}\left(H_{t+1}-I_{t+1}\right)=(1+r)\left[W_{t}-\pi_{t}-\left(y_{t}-\pi_{t}\right)\right],
\end{aligned}
$$


and that

$E_{t}\left(D_{t+1}-\Pi_{t+1}\right)-(1+r)\left[D_{t}-\Pi_{t}-\left(P_{t}-\pi_{t}\right)\right]$.

Straightforward substitution of (A.6) and (A.7) into (A.3), (A.4) and (A.5) confirms that (6) holds: Thus, the sequence of cash-in-advance contracts is feasible. Furthermore, insteac of paying $P_{t}$ in each period, the courtry need only pay $A_{s} \leq P_{s}-\pi_{s}$ in period $s$ and $\mathrm{P}_{t}-\mathrm{q}\left(\mathrm{y}_{t}-\pi_{t}\right)-\pi_{t} \leq \mathrm{P}_{t}-\pi_{t}$ for $t>$ s, with equality holding only when $q-0$. Thus $q-0$ and, by (A, 2), $D_{t} \leq \pi_{t} \forall t$ Q.E.D. 


\section{REFERENCES}

Alexander, Lewis $S$. "The Legal Consequences of Sovereign Default." Mimeo, Federal Reserve Board, Washington D.C., 1987.

Atkeson, Andrew. "International Lending with Moral Hazard and Risk of Repudiation." Mimeo, Stanford University, November 1987 .

Bulow, Jeremy, and Rogoff, Kenneth. "A Constant Recontracting Model of Sovereign Debt," University of Wisconsin: Social Systems Research Institute Working Paper no. 8711, October 1987.

Cole, Harold L., and English, William B. "Default, Direct Investment and International Equity Contracts," University of Pennsylvania: International Economics Research Center Discussion Paper no. 9, October 1987.

Eaton, Jonathan, and Gersovitz, Mark. "Debt with Potential Repudiation," Review of Economic Studies 48 (April 1981): 289-309.

Eaton, Jonathan, and Gersovitz, Mark. "Country Risk: Economic Aspects," in Richard J. Herring (ed.) Managing Country Risk. London: Cambridge University Press, 1983.

Eaton, Jonathan; Gersovitz, Mark, and Stiglitz, Joseph E. "The Pure Theory of Country Risk," European Economic Review 30 (June 1986): 481-513.

Eichengreen, Barry, "Til Debt Do Us Part: The U.S. Capital Market and Foreign Lending." Mimeo, University of California at Berkeley, August 1987.

Feldstein, Martin; Decarmay, Herve; Narusawa, Koei, and Krugman, Paul. Restoring Growth in the Debt-Laden Third World. New York: The Trilateral Commission, 1987.

Grossman, Hersche1, and Van Huyck, John B. "Sovereign Debt as a Contingent Claim: Excusable Default, Repudiation and Reputation." Mimeo, Brown University, 1987.

Helpman, Elhanan. "The Simple Analytics of Debt-Equity Swaps and Debt Forgiveness." Mimeo, Massachusetts Institute of Technology, September 1987.

Kletzer, Kenneth. Asymmeties of Information and LDC Borrowing with Sovereign Risk," Economic Journal 94, 1984. 
Kreps, David and Wilson, Robert. "Reputation and Imperfect Information." Journal of Economic Theory 27 (August 1982): $253-79$.

Lindert, Peter $\mathrm{H}$., and Morton, Peter j. "How Has Sovereign Debt Worked?" University of California at Davis: Institute of Governmental Affairs Research Progzam AMM Working paper no. 45, August 1987 .

Manuelli, Rodolfo E. "A General Equilibrium Model of International Credit Markets. Mimeo, Northwestern University, June 1986.

Obstfeld, Maurice, "Capical Mobilizy in the World Economy: Theory and Measurement," in $\mathrm{K}$. Brunner and A.H. Meltzer (eds.) Carnegie-Rochester Conference Series on Public Policy 24 (Spring 1936), 55-111.

Winkler, Max. Foreign Bonds: An Autopsy. Philadelphia R Swain Co., 1933 .

Wynne, W.H. State Insolvency and Foreign Bondholders, Volume II. New Haven: Yale University Press, 1951. 